\title{
'N KERKREGTELIKE VERKENNING VAN DIE BELEWING VAN KERKLIKE EENHEID IN EN OOR VOLKS- EN TAALGRENSE
}

\author{
A. le R. du Plooy \\ Departement Ekklesiologie \\ Potchefstroomse Universiteit vir $\mathrm{CHO}$ \\ POTCHEFSTROOM
}

\begin{abstract}
This article investigates the problem of church unity, paying special attention to unity within and acrass boundaries of language and culture. The problem is approached from a chunch canonical point of view. A symopsis is given of the resolutions and viewpoints of the three Afrikaans Churches in South Africa. The reasoning behind the different points of view of these Churches which all adhere to reformational traditions and which all function and work in the same country, is discussed critically. Finally an attcmpt is made to indicate a few canonical parameters which may be regarded as guidelines 10 address the problem of unity and diversity in the one Church of Jesus Christ our Lord.
\end{abstract}

\section{INLEIDING}

Die onderwerp is reeds vir 'n geruime tyd besonder belangrik, tans selfs gewild, maar tegelyk problematies. Dit is aktueel en gelade.

In 'n interessante redaksionele artikel skryf Wood (1990: 7-16) onlangs oor dié wêreldwye verskynsel, en stel dat dwarsdeur die geskiedenis, die godsdiens en die kerk dikwels as handlanger van die staat gedien het en dat kerke veelal geneig was om die nasionale belange te dien. Hy toon aan dat veral as gevolg van die invloed van die $\mathrm{Lu}$ therse Protestantisme en Erastianisme daar in die Reformasie van die sestiende eeu en daarna nasionale kerke onder beheer van die staat ontstaan het. "This trend was given momentum also in Roman Catholicism by what was known as Febronianism, which not only challenged papal authority over other bishops, but advocated national churches in which bishops would be subject to the secular rulers of the state" (Wood, 1990:9). Wood (1990:10) tipeer hierdie neiging wat telkens voorkom as in stryd met die katolisiteit van die kerk soos dit in die Nuwe Testament en Apostoliese Geloofsbelydenis geleer word.

Die grense en die roeping van die kerk is nie beperk tot lands- of volksgrense nie, hoewel die kerk inderdaad ook 'n roeping het ten opsigte van volke en owerhede. Ek 
bepaal my graag by die feit dat dit die roeping van die kerk is om hom as ' $n$ unieke instelling van God in die wêreld oor volks- en taalgrense heen uit te strek, sonder dat volke en tale daarmee moet verdwyn of geïgnoreer mag word.

Wie hom met kerklike eenheid besig hou, sal voortdurend in gedagte moet hou dat een wesenseienskap van die kerk - soos sy eenheid - nooit losgemaak mag word van 'n ander wesenseienskap soos die katolisiteit of ekumenisiteit van die kerk nie.

Ek beperk my tot 'n gereformeerd-kerkregtelike verkenning van die belewing van kerklike eenheid in en oor volks- en taalgrense heen. Dit behoort duidelik te word dat daar selfs binne die gereformeerd-kerkregtelike wèreld uiteenlopende aksente en gesigspunte oor die onderwerp bestaan.

Ek neem as vertrekpunt die Drie Formuliere van Eenheid waarin onder meer die gesag en genoegsaamheid van die Woord van God bely word, en waarin die leer met betrekking tot die kerk ook duidelik uiteengesit word.

Dit is my oortuiging dat die onderwerp - prinsipieel beskou - nie vanuit 'n evolusionêre gesigspunt benader kan word nie, maar vanuit 'n eksegetiese en openbaringshistoriese hoek. Hiervolgens is die Woord van God die norma normans en die Belydenis die norma normata. Die historiese ontwikkeling of teologiese bydraes in die verloop van die geskiedenis kan derhalwe nie normatief wees nie, hoewel dit dikwels verhelderend en insiggewend is omdat die Heilige Gees die kerk sodanig verlig dat die openbaring in die Woord verstaan kan word. Tegelyk is ek bewus van die moontlike invloed van die sogenaamde natuurlike teologie wanneer die unieke aard van die kerk aan die blote sigbare bestaanswyse van die kerk in die wêreld opgeoffer word (vgl. Jonker, 1989:17. 19).

Hiermee behoort dit duidelik te wees dat politieke strominge en staatkundige modelle - veral binne die huidige politieke problematiek in Suid-Afrika - geensins ' $n$ rigtinggewende of bepalende faktor ten opsigte van die feit en wyse van kerklike eenheid oor volks- en taalgrense kan of mag wees nie. Omgekeerd is dit wel die roeping van die kerk om in leer en lewe 'n voorbeeld van gesonde verhoudinge in die samelewing te wees, en om getuienis vir vrede, versoening en geregtigheid na binne en buite die geloofsgemeenskap te lewer (vgl. Van Wyk, 1988:16).

\section{OORSIG OOR ENKEIE STANDPUNTE}

Ten einde 'n begrip te vorm van die problematiek en om te probeer bepaal waar die kernprobleme lê, gee ons kortliks 'n oorsig oor die standpunte of besluite van die drie 
Afrikaanse kerkegemeenskappe ten opsigte van die belewing van kerklike eenheid oor volks- en taalgrense heen.

\subsection{Nederduitsch Hervormde Kerk van Afrika}

Die standpunt van die Nederduitsch Hervormde Kerk van Afrika hang ten nouste saam met die kerkbegrip van die betrokke Kerk.

In terme van artikel III van die Kerkwet beskou die Kerk homself as 'n volkskerk. Die Kerk bestaan uit al die gemeentes van die Nederduitsch Hervormde Kerk van Afrika en word deur die Algemene Kerkvergadering regeer (artikel XXV en Bepaling 11). Die kerk staan onder bestuur van die ampte-in-vergadering (Pont, 1981:221-223).

Lidmaatskap van die Kerk is beperk tot blankes. Die Kerk beskou die sendingopdrag volgens Matteus 28:19 so dat daar volkskerke onder die verskillende volksgroepe gevorm kan word (artikel III van die Kerkwet).

'n Motivereing vir die bestaan van selfstandige volkskerke kan in die volgende - mees resente - standpunt van hierdie Kerk gesien word: "Die Kerk meen dat organisatoriese eenheid nie in die eerste plek 'n skriftuurlike eis is nie. Volkskerke word opgerig wat mekaar as kerke erken, mekaar raadgee en bystaan en wat met mekaar in gesprek bly oor veral konfessionele eenheid" (Handelinge Tussenkerklike Kommissie, 1982 1989:581).

Tussen die selfstandige volkskerke word wel kontak gehou en hulp gegee, maar geen meerdere vergaderinge word gehou nie (Handelinge Tussenkerklike Kommissie, 1982 - 1989:584). Verder het die Kerk by geleentheid gestel: "Indien daar periodieke behoeftes sou ontstaan dat ' $n$ groep kerke saam, oor bepaalde aspekte van die waarheid moet besin, is die Nederduitsch Hervormde Kerk bereid om in die verband 'n werkprogram oor nasionale grense heen te ontwikkel (Handelinge Tussenkerklike Kommissie, 1978 - 1981:305; ook 1955 - 1977:123-127).

Die belewing van kerkeenheid tussen hierdie volkskerke (tans is daar twee) vind dus op 'n ad hoc-basis plaas, maar daar word nie op strukturele of institusionele wyse gestalte gegee aan die konfessionele en historiese bande wat die Kerke met mekaar het nie (vgl. Du Plooy, 1986:34-35).

Hoewel artikel III van die Kerkwet reeds indringend deur 'n studiekommissie bestudeer is, en daaroor op die laaste Algemene Kerkvergadering in 1989 gerapporteer is, is besluit om dit in sy huidige vorm te behou. Ds. Banda (1989:9) van die Hervormde 
Kerk in Suidelike Afrika het op genoemde vergadering gesê dat artikel III in sy huidige vorm ' $n$ verleentheid vir baie swart lidmate van die Hervormde Kerk in Suidelike Afrika is.

Ofskoon artikel III steeds onder bespreking is, ook in die vergaderinge van die Tussenkerklike Kommissie, lyk dit nie of die belewing van kerklike eenheid oor volks- en taalgrense heen in die geledere van Nederduitsch Hervormde Kerk soveel belangstelling geniet soos in die ander twee Afrikaanse Kerke nie.

Met betrekking tot kerklike eenheid met die ander twee Afrikaanse Kerke in volksverband, meen die Nederduitsch Hervormde Kerk dat hoewel dié eenheid van eenheid in die waarheid afhang en eerstens geestelik en konfessioneel is, dit moontlik is dat organisatoriese eenheid realiseerbaar is namate die Kerke mekaar in die kerklike gesprek vind (Handelinge Tussenkerklike Kommissie, 1982 - 1989:581).

Hierdie standpunt gaan verder as die aanvanklike oortuiging in die Nederduitsch Hervormde Kerk, naamlik dat die bestaan van drie Afrikaanssprekende Kerke nie afbreuk doen aan die "Bybels-Reformatoriese visie oor die eenheid van die kerk van Christus nie" (Engelbrecht, 1978:18; Van Aarde, 1989:462-463).

Van Zyl (1978:24-26) het reeds van die aanvanklike oortuiging verskil, en gestel dat die afsonderlike bestaan van die drie Kerke tot verwarring lei, ' $n$ struikelblok vir die evangelie is en inderdaad ongehoord is. Die roeping tot eenheid word deur hom voorgestel as 'n proses van eenwording.

\subsection{Die Nederduitse Gereformeerde Kerk in Suid-Afrika}

In die geledere van die Nederduitse Gereformeerde Kerk in Suid-Afrika, asook in die midde van die Familie van die Nederduitse Gereformeerde Kerke het die vraag na die belewing van kerklike eenheid veral sedert die sewentigerjare brandend aktueel geword. Daar kan selfs van spanning in daardie geledere gepraat word (Du Plooy, 1986:35 e.v.; vgl. oorsig van Theron, 1986:194-210).

Die verhouding tussen die lede van die Familie van Kerke is aanvanklik in die publikasie Ras, volk en nasie en volkereverhoudinge in die lig van die Skrif (Ned. Geref. Kerk, 1975) uiteengesit. Dit is in 1986 vervang met die bekende publikasie Kerk en Samelewing (Ned. Geref. Kerk, 1986).

Kleynhans (1977:301-316) het aangetoon hoe die kerkregtelike verhouding tussen die Nederduitse Gereformeerde Kerk en ander Kerke wat uit hom gegroei het, histories 
ontwikkel het. Hy toon aan hoe daar uiteindelik afsonderlike en selfstandige kerkverbande (Kerke) ontstaan het (vgl. ook Kleynhans, 1973).

Dit is opmerklik hoe die motivering vir die bestaan van afsonderlike kerkverbande binne die Nederduitse Gereformeerde Kerkfamilie van 1857 tot 1974 verander het: in 1857 het die Sinode dit besluit op grond van "de zwakheid van sommigen", terwyl die Algemene Sinode van 1974 soos volg besluit het: "Die bestaan van afsonderlike Nederduitse Gereformeerde Kerkverbande vir verskillende bevolkingsgroepe word erken as in ooreenstemming met die Skriftuurlike meervormige bestaanswyse van die kerk ..." - Ras, volk en nasie (Ned. Geref. Kerk, 1975:83).

In Kerk en Samelewing (Ned. Geref. Kerk, 1986:44) blyk dit dat besef is dat die eenheid in die Familie van Nederduitse Gereformeerde Kerke steeds duideliker tot uitdrukking gebring moet word: "Die vraag hoe hierdie sigbare eenheid daar moet uitsien, sal langs die weg van indringende samesprekings tussen die verskillende lidkerke, in die lig van die eise van die Skrif en van praktiese omstandighede, uitgemaak moet word."

Die Federale Raad van die Nederduitse Gereformeerde Kerke is tans die enigste amptelike liggaam waarin die verskillende lidkerke saamkom en gesamentlik beraadslaag. Dit is geen meerdere vergadering nie, maar 'n beraadslagende vergadering met onder meer die volgende bevoegdheid (vgl. art. 6, Konstitusie van die Federale Raad, Kerkordeboekie, 1978:50):

- "Elkeen van die samestellende lidkerke behou sy wetgewende, regsprekende en administratiewe bevoegdhede".

- "Die Raad het ook geen bevoegdheid om besluite oor die interne partikuliere aangeleenthede van die lidkerke te neem nie".

- "Die besluite van die Raad is ten opsigte van die lidkerke bloot adviserend".

In Kerk en Samelewing (Ned. Geref. Kerk, 1976:44) word duidelik gestel dat elke lidkerk oor die bevoegdheid beskik "om desnoods hulle eie belydenisgrondslag te wysig".

Die resente standpunt ten opsigte van kerkeenheid oor nasionale grense word amptelik soos volg geformuleer: "Kerkeenheid oor nasionale grense hoef nie noodwendig in een kerkverband tot openbaring te kom nie. Die eenheid word ook beleef by wyse van gesamentlike belydenis, byeenkomste, onderlinge hulpbetoon, en gemeenskaplike onderneminge. Daar bestaan afsonderlike kerke onder die verskillende bevolkingsgroepe en wat byvoorbeeld in die Federale Raad van NG Kerke saamgebind word" (Handelinge Tussenkerklike Kommissie, 1982-1989:581-582). 
Die Nederduitse Gereformeerde Kerk werk ook met die gedagte van die eenheid en verskeidenheid, en stel in Kerk en Samelewing (1986:23) die volgende: "In die strukturering van die kerk kan vir taal en kultuurverskille wat met die verskeidenheid van volke saamhang, voorsiening gemaak word, maar dan op 'n wyse wat die eenheid van die kerk nie benadeel nie."

Daar word ook geen kerkregtelike gronde gesien vir meerdere vergaderinge oor nasionale grense heen nie (Handelinge Tussenkerklike Kommissie, 1982-1989:584).

Die standpunt hang grootliks saam met die kerkbegrip. Hiervolgens is die Nederduitse Gereformeerde Kerk 'n institutêre eenheid, oftewel 'n ecclesia instituta (vgl. Du Plooy, 1982:405 e.v.). Derhalwe vorm die verskillende Nederduits Gereformeerde kerkverbande institutère eenhede wat selfstandig naas mekaar bestaan. Sedert 1962 beskou die Nederduitse Gereformeerde Kerk homself as 'n korporatiewe eenheid en as 'n regspersoon, saamgestel deur die Nederduitse Gereformeerde gemeentes (vgl. Fourie, 1973:63, 82-83).

Binne die Nederduitse Gereformeerde Kerk asook in die geledere van die Familie van Nederduitse Gereformeerde Kerke vind daar tans indringende gesprekke oor veral die graad en aard van die eenheid en eenheidsbelewing oor volks- en taalgrense heen plaas.

Dit is bekend dat die Nederduitse Gereformeerde Sendingkerk en die Nederduitse Gereformeerde Kerk van Afrika reeds besig is om onder meer uit hulle geledere 'n "verenigende Gereformeerde Kerk" tot stand te bring.

Die kerkeberaad tussen die lede van die Familie van Nederduitse Gereformeerde Kerke wat in Maart 1989 in Vereeniging plaasgevind het, het laat blyk dat kerklike eenheid oor etniese grense in ernstige diskussie is en dat daar geworstel word oor bepaalde verskille rondom die eenheidsbelewing (vgl. Die Kerkbode, (1989a:1,2,5,6) en Die Kerkbode $(1989 \mathrm{~b}: 1,2,6)$ ). Hiervolgens is dit duidelik dat die beraad (uitgesonderd die verteenwoordigers van die Nederduitse Gereformeerde Kerk) besluit het om hom te verbind tot die totstandkoming van een, verenigde, nie-rassige Gereformeerde Kerk in suidelike en sentraal-Afrika. Die Nederduitse Gereformeerde Kerk se standpunt was dat hy nog nie gereed is om hom aan 'n bepaalde model vir so 'n toekomstige kerk te verbind nie. Die Algemene Sinodale Kommissie (ASK) het verder besluite geneem oor die wyse waarop groter uitdrukking gegee moet word aan kerkeenheid: op plaaslike vlak moet groter samewerking bewerkstellig word en daar moet na strukture gesoek word om beslag aan die eenheid tussen die Kerke te gee.

"Die ASK het 'n dinamiese evolusionêre model van kerkeenheid in gedagte waarin 
eenheid en ook verskeidenheid tot hul reg sal kom" (Die Kerkbode, 1989b).

Ons bemerk dus 'n dringendheid in die Familie van die Nederduitse Gereformeerde Kerke wat sekerlik ook verstaan moet word teen die agtergrond van veral die ontstaan van die Belharbelydenis in die Nederduitse Gereformeerde Sendingkerk in 1982, en die bewering dat apartheid die versoening in Christus en die eenheid van die kerk wesenlik bedreig en derhalwe 'n status confessionis daarstel (vgl. gegewens en diskussie hieroor by Van Wyk, 1985:49-77).

Met betrekking tot kerklike eenheid met die ander twee Afrikaanse Kerke in dieselfde volks- en taalverband staan die Nederduitse Gereformeerde Kerk en die Gereformeerde Kerke op dieselfde standpunt, naamlik dat die bestaan van drie afsonderlike Kerke 'n sondige geskeidenheid is, en dat dit ons roeping is om deur middel van gesprekke eventueel in een kerkverband te tree (Handelinge Tussenkerklike Kommissie, 1982. 1988:581).

\section{Die Gereformeerde Kerke in Suid-Afrika}

Die vraag na die aard en belewing van kerklike eenheid oor volks- en taalgrense heen het veral sedert die begin sestigerjare in die geledere van die Gereformeerde Kerke in Suid-Afrika besondere aandag geniet.

Van Wyk (1988:21 e.v.) gee 'n oorsig oor die historiese ontplooiing met betrekking tot die tydperk 1869-1985 (vgl. ook Du Plooy, 1982:399 e.v.).

Van Wyk onderskei drie periodes:

- Die eerste periode (1869-1958) laat blyk volgens besluite van sinodes dat daar skeiding tussen blankes en gekleurdes in die eredienste en kerklike lewe moet wees.

Die sinode van 1958 (Handelinge: 266-270) besluit dat vermenging op kerklike terrein en gemengde kerkformasie ongeoorloof is aangesien dit die nasionale identiteit en roeping kan ondermyn, veral van die getalswakkere blankes.

* Die tweede periode (1961-1967) word gekenmerk deur 'n besliste wending, veral vanweë die bydrae van prof. W.J. Snyman (vgl. Snyman, 1977). Naas die verskeidenheid kry die eenheid nou ook besondere aandag.

In 1961 (Handelinge: 115-119) besluit die sinode om ras- en volksvermenging as beginsel en reël op kerklike gebied te verwerp, en nasionale kerkverbande word in 
die vooruitsig gestel. Dit is gestel dat die geestelike eenheid op 'n dieper vlak as die natuurlike en organisatoriese lê, maar tog moet die eenheid ook institutêr tot uitdrukking kom vanweë die eenheid in leer, diens en tug.

In die daarop volgende jare word geboorte gegee aan ' $n$ vergadering bekend as die algemene sinode omdat kerkverband oor nasionale grense heen in 'n algemene sinode tot uitdrukking moet kom (vgl. Du Plooy, 1986:39). Hiermee het die Gereformeerde Kerke die eerste Afrikaanse kerkgemeenskap geword wat besluit het dat daar ook 'n sigbare belewing van kerklike eenheid oor nasionale en taalgrense heen moet wees.

In 1967 neem die nasionale sinode (Handelinge: 359 e.v.) belangrike besluite oor die ekumeniese roeping van die kerk waarin duidelike uitsprake gegee word oor kerklike eenheid oor geografiese en nasionale grense heen en die gedagte van volkskerke afgewys word.

* In die derde periode (1968-1985) tree daar volgens Van Wyk (1988:24) opmerklike verskuiwings na vore. Reeds in 1970 (Handelinge: 361 ) besluit die nasionale sinode "hoewel die gemeenskaplike band deur die algemene sinode gelê word, behoort daar ook 'n onderlinge kontak te wees tussen mindere vergaderings waar nodig, en op 'n wyse soos deur hulle bepaal". In 1985 (Handelinge: 435 e.v.) word besluit dat afsonderlike instituering wenslik mag wees, maar dat ras, volk of kleur nie die kriterium van lidmaatskap mag wees nie.

Die huidige stand van sake in die gemeenskap van Gereformeerde Kerke in SuiderAfrika is dat (plaaslike) kerke oor volks- en taalgrense in een kerkverband met mekaar staan en so gestruktureer word dat daar tot op nasionale vlak afsonderlik in meerdere vergaderinge saamgekom word, maar gesamentlik in 'n algemene sinode (vgl. art. 51 Kerkorde; ook Handelinge Tussenkerklike Kommissie, 1982-1989:582).

Snyman (1977:112-113) noem hierdie eenheid 'n eenheid in verskeidenheid, en meen verder dat dit belangrik is dat daar toesig sal wees in die kerkverband vir die bewaring van die eenheid van die belydenis.

Die Gereformeerde Kerke bly dus by die prinsipiële uitspraak van die sinode van 1973 (Handelinge: 285-286): "Onafhanklike nasionale kerke is net so onverenigbaar met die presbiteriale kerkregering as onafhanklike plaaslike kerke ... kerkverband oor nasionale grense lê in lyn met die Calvinistiese reformasie in onderskeiding van die Lutherse (cuius regio eius religio)".

Gesprekke in die kerkverband van die Gereformeerde Kerke in Suidelike Afrika han- 
del nie meer oor die vraag of kerklike eenheid struktureel oor volks- en taalgrense heen belewe en gereël moet word nie, maar fokus nou veral op die fynere wyses van uitlewing en die belewing daarvan. Daar is inderdaad verskil van mening. Sommige dink in terme van geografies-bepaalde meerdere vergaderinge en slegs een nasionale (of algemene sinode) met die verdwyning van die verskillende nasionale sinodes. Ander dink weer in terme daarvan om die algemene sinode se samestelling so te wysig dat daar 'n groter deputering sal wees met die behoud van nasionale sinodes (vgl. Spoelstra, 1988:37 e.v.; Jaftha, 1988:33-36; Handelinge van die nasionale sinode 1988:241 e.v.; Du Plooy, 1989a).

\section{$2.4 \quad$ Samevatting}

Die huidige standpunte en besluite van kerke met 'n reformatoriese agtergrond en inslag is dus uiteenlopend. Verskillende benaderingswyses en standpunte of modelle kan bespeur word:

- Die Nederduitsch Hervormde Kerk het 'n standpunt wat ons sou kon tipeer as insidentele kommunikasie tussen selfstandige volkskerke in een geestelike geloofsgemeenskap. Hierdie Kerk probeer kommunikasie handhaaf en handel konstruktief soos geleenthede voorkom.

- Die Nederduitse Gereformeerde Kerk handhaaf 'n federatiewe geloofsgemeenskap. Tans is daar by die Algemene Sinodale Kommissie sprake van 'n dinamiese evolusionêre model waarin eenheid en ook verskeidenheid tot hulle reg sal kom.

- Die Gereformeerde Kerke in Suidelike-Afrika is een plurale geloofsgemeenskap waarvolgens gepoog word om die beginsel van eenheid in 'n verskeidenheid tot uitdrukking te bring. Ook in hierdie geledere is die huidige strukturele wyse waarvolgens die kerke (gemeentes) mekaar in die kerkregering asook in die gewone belewing van die eenheid bystaan onder bespreking, en kan bepaalde ontwikkelinge sekerlik nog verwag word.

\section{OORSAAK VIR VERSKIILENDE GESIGSPUNTE EN PROBLEME}

Ruimte ontbreek om deeglik in te gaan op al die oorsake of redes vir die verskillende standpunte wat na vore gekom het. Op sigself behoort dit 'n interessante (moontlik noodsaaklike) studie te wees om noukeurig deur te dring tot al die teologiese (en ander) strominge en rigtings wat agter die huidige verskille tussen die drie Afrikaanse Kerke le - ook ten opsigte van die verskillende benaderinge rondom kerklike eenheid 
in en oor volks- en taalgrense heen. Ons vestig die aandag op slegs enkele aspekte in hierdie verband.

Dit is opmerklik dat die verskil in kerkbegrip, die verskil ten opsigte van die begrip kerkverband, die volkskerk-gedagte en die verhouding of verband tussen owerheidkerk-volk asook die aard en belewing van kerklike eenheid en katolisiteit van die mees prominente faktore is wat tot die verskillende standpunte aanleiding gee.

Agter hierdie verskille lê weer die invloed van die Lutherse territoriale sisteem waarvolgens landskerke as selfstandige eenhede bestaan, juis in reaksie teen die Middeleeuse Roomse corpus christianum-denke. So ook die invloed van strominge soos die Erastianisme, kollegialisme en presbiterianisme (vgl. Pont, 1986:28 e.v.; 1987:25 e.v.; Spoelstra, 1984:50 e.v.).

Verder het die ontwikkelinge in Nederland gedurende die $19 \mathrm{e}$ en $20 \mathrm{e}$ eeu 'n bepaalde invloed op die kerklike situasie in Suid-Afrika uitgeoefen - veral die Afskeiding van 1834 en die Doleansie van 1886 (vgl. Spoelstra, 1988:38 e.v.; Du Plooy, 1979:110 e.v.).

Terwyl bogenoemde opmerkings in die algemeen gestel word, vestig ons voorts die aandag op enkele besondere of prominente aspekte wat moontlik as primêre faktore beskou kan word waarom die huidige problematiek rondom kerklike eenheid oor volks- en taalgrense heen so aktueel geword het en verskillend benader word. In hierdie verband kyk ons agtereenvolgens kursories na die prominensie van die volkskerkgedagte, die kerkbegrip van die Nederduitse Gereformeerde Kerk en na die invloed van'n teoloog soos A. Kuyper met sy pluriformiteitsleer.

\subsection{Die volkskerk-gedagte}

Dit is moeilik om die begrip volkskerk werklik te begryp, en nog moeiliker om die verskillende motiveringe wat hedendaags aangevoer word vir die bestaan daarvan enersyds met mekaar in ooreenstemming te bring en andersyds teologies te onderskryf. Wat dit kompliseer is byvoorbeeld die feit dat argumente wat in resente tye in die geledere van die Nederduitsch Hervormde Kerk van Afrika ten gunste van 'n volkskerk aangevoer word, verskil van wat tradisioneel en histories die geval was in veral die Nederlandse Hervormde Kerk sedert 1816. Sommige teoloë wil die volkskerk vanuit die Skrif motiveer en daarin begrond (vgl. Van der Westhuizen, 1989) terwyl ander weer sterk fokus op die geskiedenis en dit as bewysvoering gebruik (vgl. Pont, 1986:28. 78). Volgens 'n koerantberig sê prof. Bart Oberholzer (1990) byvoorbeeld: "Die Kerk is wel algemeen, maar die geskiedenis het geleer dat kerke volksgestaltes aanneem" (my kursivering). 
Ruimte ontbreek om volledig die problematiek rondom die volkskerk-gedagte te behandel, maar dit is tog belangrik om kortliks enkele kritiese opmerkings daaroor te maak omdat die volkskerk-gedagte grootliks diametraal teenoor kerklike eenheid oor volks- en taalgrense heen staan. Ek beperk my tot die aanduiding van wat na my mening die eintlike pilare is waarop die volkskerk-gedagte tradisioneel berus - sonder om te beweer dat dit alles vandag nog aanvaar word deur diegene wat vir 'n volkskerk pleit.

Die historiese lyn - vanaf Konstantyn die Grote - loop deur die eeue tot vandag en tegelyk is daar ook ' $n$ bepaalde historiese verband tussen die idee van 'n staatskerk en volkskerk. Teologiese denke van teoloë soos Kraemer, Van Ruler, Hoekendijk en Hoedemaker kan as besonder belangrik vir die gedagte van 'n volkskerk beskou word. Die pilare waarop die volkskerk-gedagte tradisioneel gebou is, is die volgende:

- 'n Bepaalde beskouing ten opsigte van die verhouding tussen die Ou-Testamentiese en Nuwe-Testamentiese volk.

Hoedemaker was van mening dat vanweë die eenheid tussen die Ou en Nuwe Testament die verhouding tussen kerk en volk in die Ou Testament eksemplaries vir die Nuwe-Testamentiese verhouding tussen kerk en volk is (Buys, 1970:260; vgl. Pont, 1986:56-58).

- Die genadeverbond, kinderdoop en kerk as corpus permixtum

Teen die agtergrond van die Roomse corpus christianum-denke gedurende die Middeleeue was elke mens volgens rykswet verplig om hom te laat doop met die gevolg dat volk en kerk identies was. Na die Reformasie van die 16e eeu het dié gedagte by sommige bly bestaan (vgl. Pont, 1986:30 e.v.) omdat as ideaal beskou was dat die hele volk ook kerk moet wees. Uitgaande van die feit dat kinders in die kerk ontvang word op grond van die sigbare sakrament van die doop as die teken van die verbond, en aangesien verbond en uitverkiesing nie saamval nie, is gemeen dat die kerk altyd 'n corpus pennixtum is. Anders gestel: die kiem van 'n volkskerk sit in die opdrag dat die gelowiges en hul kinders (of nasate) gedoop moet word (vgl. Oorthuys en Kromsigt, 1933:89 e.v.).

- Die hegte verband tussen volk-owerheid-kerk

Die Barthiaanse invloed op die gedagte van 'n volkskerk bestaan veral daarin dat dit gelei het tot die aksentuering van die kerk se gerigtheid tot die volk en die wêreld. Die kerk moet solidêr wees met die wêreld; dit moet nie soseer 'n kerk van die volk wees nie, maar 'n kerk vir die volk, in lyn met die apostolaatsteologie van Van Ruler en 
andere (vgl. Buys, 1970:349). Artikel 36 van die Nederlandse Geloofsbelydenis word so verstaan dat die owerheid net soos die kerk die roeping het om God se heerskappy oor die volk en fasette van die volkslewe te laat realiseer, en om die volk se lewe te kersten. Dit is 'n idedal wat egter nie altyd verwesenlik kan word nie, hoewel dit nie die ideaal self ontkrag nie (vgl. Pont, 1986:32 e.v.; 1987:34).

Een saak wat vir die doeleindes van hierdie artikel belangrik is, is dat die basiese bedoeling van ' $n$ volkskerk vandag in Suid-Afrika impliseer dat daar selfstandige Kerke wat mede-bepaal word deur taal, lewenstyl, kultuur en volk naas mekaar en los van mekaar moet bestaan. Die woord Kerk beteken in hierdie sin in die geledere van die Nederduitsch Hervormde Kerk van Afrika, die samevoeging van plaaslike kerke of gemeentes binne ' $n$ groep wat as blankes bekend is (vgl. Handelinge Tussenkerklike Kommissie, 1982-1989:473; ook Artikels II en III van die Kerkwet van die Nederduitsch Hervormde Kerk van Afrika). Die vraag sou gestel kon word wat presies die verband tussen die begrippe volk en blankes in genoemde artikel III is, want die blankes behoort seker nie almal aan dieselfde volk nie, en praat ook nie dieselfde taal nie.

Enkele opmerkings en kritiese vrae wat na aanleiding van die volkskerk-gedagte gestel kan word, is onder meer die volgende:

- Die enigste en werklike waardering wat teenoor die gedagte van 'n volkskerk uitgespreek kan word, is dat dit die roeping van die kerk ten opsigte van die volk (waarvan gelowiges natuurlik deel bly nadat hulle tot geloof gekom het) beklemtoon. Kerk en volk staan natuurlik nooit los van mekaar nie (vgl. Coetzee, 1985). Tog is dit sekerlik nie nodig om volkskerk genoem te word nie as die kerk, kragtens sy wese en roeping, in elk geval van God die opdrag ontvang het om van die volk Israel, maar tegelyk van al die volke, dissipels van Jesus Christus te maak.

- Die volkskerk strem egter die eenheid van die Godsvolk wat hom oor alle volke, tale en nasies uitstrek, en maak daarvan Godsvolke in die meervoud. Sodoende tas dit die belydenis van die katolisiteit en ekumenisiteit van die kerk aan. Op die gebied van die kerkregering lei dit tot 'n vorm van independentisme, want onafhanklike nasionale kerke is net so onversoenbaar met die ware Christusregering van God se kerk as onafhanklik plaaslike kerke.

- Steun vir 'n volkskerk kan nie by Calvyn gevind word nie (so byvoorbeeld Pont, 1986:31 e.v.; 1987:35-38). In Calvyn se Institusie (IV, 1, 9) blyk duidelik die teendeel. McNeill (1988:42-55) het in hierdie verband ' $n$ insiggewende artikel geskrywe. Daarin stel hy: "Calvin thinks of mankind always primarily as a unit ... Calvin does not concern himself with racial differences in the contemporary world" (McNeill, 1988:53). Hy verwys ook na 'n preek van Calvyn oor Galasiërs 6:9-11 
waarin Calvyn die volgende gese het: "Even in dealing with a Moor or a Barbarian, from the very fact of his being a man he carries about with him a looking-glass in which we can see that he is our brother and our neighbor" (McNeill, 1988:53). Wallace (1959:150) wat na genoemde opmerkings verwys het, het verder opgemerk: "These two facts - that man is created in the image of God, and that all share in a common human nature - are the foundation of all Calvin's teaching about human relationships."

- Word die probleem met die volkskerk-gedagte nie moontlik opgelos of minstens krities beoordeel wanneer die kerk eerder vanuit sy innige verband en verhouding met die koninkryk van God benader word nie? Dit is tog die verkondiging van die koninkryk van God wat tot die kerk gelei het (Du Plooy, 1982:34 e.v.). Die kerk behoort primêr vanuit die (koninkryk) van die hemele, en nie vanuit die aarde (die volk as 'n gemeenskap van mense) beskou te word nie.

- Die faktor wat gelowiges werklik as 'n eenheid saambind is sonder twyfel geloof, en doop (verbond) en belydenis en nie primêr ons volkskap nie. Volkskap wat kan bly voortbestaan is eerder die gevolg van geloofseenheid as die voorwaarde daarvan. Werklike geloofseenheid is ook afhanklik van voortdurende binding en handhawing van die gemeenskaplike belydenis, en dit is weer afhanklik van onderlinge gesprek en gesamentlike besluitneming. Die volkskerk-gedagte kompliseer hierdie moontlikheid en maak dit inteendeel moontlik dat selfstandige volkskerke mettertyd van mekaar kan vervreem en elk sy eie konfessionele weg kan volg.

\subsection{Die kerkbegrip van die Nederduitse Gereformeerde Kerk}

Uit wat hierbo in 2.2 met betrekking tot die standpunte van die Nederduitse Gereformeerde Kerk gestel is, is dit duidelik dat hierdie Familie van Kerke in 'n proses van indringende gesprekvoering en diskussie oor die saak en belewing van kerklike eenheid oor volks- en taalgrense heen is - soos immers ook die geval is by die Gereformeerde Kerke in Suid-Afrika.

Een van die basiese verskille tussen die Nederduitse Gereformeerde Kerk en die Gereformeerde Kerke sentreer juis rondom die kerkbegrip, veral oor die punt dat eersgenoemde homself as 'n selfstandige kerkverband (ecclesia instituta) naas die ander in die familie van (eweneens) selfstandige Nederduitse Gereformeerde Kerke beskou.

Dit mag moontlik belangrik wees dat gesprekvoering oor die aard en wyse van die eenheidsbelewing oor volksgrense heen nie by die eenheid moet begin nie, maar by die begrip kerk, en verder by die vraag wat presies alles die heersende kerkbegrip bepaal het. 
Britz (1985:432-451) het aangetoon dat die Nederduitse Gereformeerde Kerk in sy nadenke en ontwikkeling van sy kerkbegrip asook sy ordening van die kerklike lewe by drie onderskeie Protestantse kerklike tradisies aansluiting gevind het, elk met sy eie standpunte en nuanseringe:

Allereers (gedurende die eerste kwart van die negentiende eeu) was daar 'n oriëntering aan die Nederlandse (Hervormde) kerkregtelike denke mel sy tipies kollegiale inkleding en reglementele praktyk. Daarna, gedurende die laaste kwart van die (negentiende eeu), word die inslag van die juridiese presiesheid van die Skotse presbiterianisme in sy kerklike en teologiese denke opgevang. In die 20e eeu word die kerkreg van die Nederlandse Gereformeerde Kerke bygehaal toe daar in die bresse getree is vir die selfstandigheid van die gemeente (Britz, 1985:432).

N.J. Hofmeyr se vertolking van die kerk was dat dit 'n oorkoepelende kerkgenootskap is. Hiermee het hy aangesluit by die kollegialistiese denke van De Mist en die Nederlandse teoloog Rooyaards (Britz, 1985:434-438; Du Plooy, 1989b:2-11).

Met betrekking tot die kerkregtelike ontwikkeling in die Kaaps-Hollandse Kerk vir die tydperk 1804-1870, konkludeer Britz (1985:438) dat die kerk beskou is as 'n sinodale en strukturele kerkverband. Hy noem dit 'n sentripetale kerkbegrip. Hy bevind dat dit op 'n nie-teologiese begrip van die kerk berus waarin Skriftuurlike en konfessionele kerkbegrippe gemis word.

Die tweede kerkregtelike tradisie wat volgens Britz (1985:438-443) groot invloed op die kerkregering in die Nederduitse Gereformeerde Kerk uitgeoefen het, was die Skotse presbiterianisme. Dit is veral gestimuleer deur die feit dat 'n handboek vir kerkreg van Skots-presbiteriaanse oorsprong, naamlik John Macpherson se Presbyte. rianism, aan die Kweekskool voorgeskryf was. Vanaf ongeveer 1886 is die kerkregtelike denke vir meer as dertig jaar hierdeur gevorm.

Die kerkbegrip volgens die presbiterianisme is basies kerksentries en sinodaal bepaal. Hiervolgens word kerklike meerdere vergaderinge met die kerk self geassosieer en word die kerkverband beskou as 'n oorkoepelende struktuur. Die begrippe kerk en kerkverband het presies met mekaar saamgeval. Volgens Macpherson se standpunte word kerkregering uiteindelik niks anders nie as kerklike magsbeoefening omdat die kerklike strukture met gesag daartoe beklee is (Macpherson, s.a.:103 e.v.).

Die derde faktor wat die kerkregtelike denke grootliks beïnvloed het, was die bydrae onder leiding van prof. B.B. Keet wat in 1919 aan die Seminarium te Stellenbosch bevestig is. Hy was soos soveel ander Afrikaanse teoloë 'n student van A. Kuyper. Waar onder invloed van Rooyaards (en ook H.G. Kleyn) die aksent op die sogenaamde algemene kerk geplaas is, het Kuyper en ook ander soos Rutgers en De Savornin 
Lohman die plaaslike kerk sterk beklemtoon (vgl. Du Plooy, 1979:110 e.v.). Keet het hom veral deur Kuyper laat lei en so in botsing gekom (soos ook J.A. du Plessis van die Gereformeerde Kerke) met J. du Plessis (vgl. Britz, 1985:445; Du Plessis, 1925).

Gedurende die laaste aantal dekades word daar in die geledere van die Nederduitse Gereformeerde Kerk self al meer krities na sy kerkbegrip gekyk en ernstig gepoog om weg te beweeg van die kollegialistiese, presbiteriaanse en sinodokratiese kerkbegrip.

Hoekom beskou ek hierdie opmerkings oor die agtergrond van die heersende kerkbegrip wat nog aan die betrokke kerk se kerkorde en kerkregering ten grondslag le, so belangrik?

Die antwoord is omdat solank daar nog elemente bly bestaan wat die kerkregering as 'n vorm van magsuitoefening beskou en solank kerk met kerkverband geïdentifiseer word, bestaan die gevaar dat die kerk foutiewelik met selfstandige strukture geassosieer kan word. Verder kan die kompleetheid van die plaaslike kerk onder leiding van die ampte (dienste) nie tot sy volle reg kom wanneer daar 'n spanning ('n dualiteit of bi-polariteit) tussen die plaaslike kerk en die selfstandige kerkverband (met sy sinodale struktuur) bestaan nie. Dit mag ook 'n rol speel wat kerklike eenheid oor volks- en taalgrense heen aan bande lê omdat die bi-polère spanning wat reeds tussen die plaaslike kerk en die selfstandige kerkverband bestaan slegs kan vergroot wanneer 'n nuwe en groter selfstandige strukturele kerkverband (kerk?) tot stand sou kom.

\subsection{A. Kuyper se pluriformiteitsleer}

'n Prominente teoloog soos A. Kuyper met sy gedagte van die pluriformiteit van die kerk (Kuyper, 1909:614-624) het beslis groot invloed op die teologiese en kerklike denke in Suid-Afrika gehad (Jonker, 1989:12). Hy het byvoorbeeld in reaksie gekom teen die volkskerk-gedagte, of teen die gedagte van 'n massa-kerk, maar hierin weer aanleiding gegee tot die ontstaan van selfstandige en onafhanklike vrye kerkverbande op grond van sy pluriformiteitsteorie (Kuyper, 1884:134 e.v.). Jonker (1989:21) beweer dat volgens Kuyper die eenheid en verskeidenheid van die kerk mekaar uitsluit, aangesien die verskeidenheid aanleiding mag gee tot 'n eie kerkformasie naas ' $n$ ander kerkverband. Sodoende, beweer Jonker (1989:22) het Kuyper se kerkbegrip meegewerk tot die ontstaan van aparte Kerke op rassegrondslag.

Op die vraag of die beroep op Kuyper se pluriformiteitsidee vir ' $n$ regverdiging van die gedagte van aparte kerke vir aparte volkere in Suid-Afrika ten regte gemaak kan word, antwoord Jonker (1989:22) dat Kuyper se motief anders was: "Sy blikpunt was die eenheid, suiwerheid en kontekstualiteit van die belydenis, terwyl hulle blikpunt die 
volkse karakter van die kerk is. Daarin is hulle sterk deur politieke motiewe beïnvloed, iets wat by Kuyper ontbreek."

Tog is dit ook waar dat Kuyper die bestaan van afsonderlike en selfstandige kerkverbande gemotiveer het vanuit die verskil in taal, kultuur, ras en volk wat sou kon lei tot die aanvaarbare etniese veelvormigheid en belydenisverskille tussen die kerkverbande (Jonker, 1989:22).

Dit is moontlik dat die Kuyperiaanse pluriformiteitsidee (behalwe die politieke situasie in Suid-Afrika) ook iemand soos P.J.S. de Klerk, wat in 1923 die doktorsgraad aan die Vrije Universiteit Amsterdam verwerf het, beïnvloed het. De Klerk (1923:165-169) pleit immers vir 'n radikale skeiding of segregasie tussen swart en blank in die kerk omdat die Christendom nie sosiale gelykheid bring nie.

\subsection{Samevatting}

Bogenoemde opmerkings was bedoel om blyke te gee van die gekompliseerdheid van die probleem, en om aan te toon dat die huidige verskille tussen gereformeerdes en tussen gereformeerde teoloë aan 'n verskeidenheid faktore toegeskryf kan word.

Die gevolg hiervan egter is dat die belydenis oor die eenheid en katolisiteit van die kerk op een of ander wyse aangetas kan word: daaroor kan gewoon gefilosofeer of geteologiseer word; dit.kan selfs gepolitiseer word; of dit kan soos Van Wyk (1988:19) dit raak opsom soveel ander weë opgaan - geminimaliseer word, gerasionaliseer, gepluriformeer, gesekulariseer, geëskatoligiseer of gespiritualiseer word; en laat ons byvoeg: op Roomse manier ge-uniformeer en geïnstitusionaliseer word (vg!. Kuyper, 1906:616).

\section{ENKELE GEREFORMEERD-KERKREGTELIKE KONTOERE}

Vervolgens gee ons aan enkele gereformeerd-kerkregtelike kontoere aandag. Hiermee wil ons kortliks fokus op prinsipiële riglyne waarbinne ons denke oor die belewing van kerklike eenheid oor volks- en taalgrense heen gelei kan word.

\subsection{Suiwere kerkhegrip}

Ruimte ontbreek om volledig op die relevante gegewens ten opsigte van die NuweTestamentiese kerkbegrip in te gaan. Ek het dit egter reeds probeer doen (Du Plooy, 
1982).

Dit bly my oortuiging dat ons vir 'n suiwere kerkbegrip asook vir die wesenseienskappe van die kerk slegs op die Woord van God aangewys is.

Jonker (1989:22) het aangetoon dat die pluriformiteitsidee van Kuyper nie die toets van die Skrif kan deurstaan nie. Dit maak die boodskap van die Skrif oor die eenheid kragteloos. Tog vind Heyns (1977:27 e.v.) en Coertzen (1981:24-25) in iets soos die kultureel-etniese motief 'n motivering vir die pluriformiteit van die kerk. Dit word dan in die dinamies-wisselende voorsienigheidsordening van God begrond wat iets anders is as die onveranderlike skeppingsordening. Myns insiens word hiermee ' $n$ weg gebaan vir 'n Skrifvreemde gedagte van selfstandige etniese kerkverbande wat met die eenheid van die kerk in stryd is. Eenheid en verskeidenheid staan hiervolgens te veel langs mekaar in plaas daarvan dat die eenheid die dominante faktor is en die verskeidenheid die kwalifiserende en verrykende faktor wat in die eenheid geakkommodeer moet word.

Van Aarde (1989:461 e.v.) se oortuiging is dat die kerk en die eenheid van die kerk ten diepste neerkom op die versamelde-gemeente-in-die-erediens. Myns insiens dring hy hiermee deur tot die kern van die saak. Verder beskou hy die ontstaan van gemeentes (meervoud) as iets wat die gevolg was van 'n konflik en partyskappe, maar laat na om dit vanuit die Skrif aan te toon. Hy verloor dit myns insiens te veel uit die oog dat die kerk ook ' $n$ geloofsgemeenskap is, en dat hierdie unieke gemeenskap (kerk in universele sin) waar dit ookal in die werreld plaaslik tot openbaring kom, met mekaar in 'n geloofsbelydende gemeenskap moet lewe (vgl. Combrink, 1986:211-234).

Die Skrif leer duidelik dat die begrip ékK $\lambda \eta{ }^{\prime} \alpha \alpha$ as aanduiding van gelowiges slegs in tweërlei betekenis gebruik word, naamlik in 'n plaaslike en algemene betekenis. Die plaaslike kerk is die algemene kerk op daardie bepaalde plek. Wanneer plaaslike kerke onderlinge geloofsgemeenskap met mekaar belewe, kom daar nie 'n nuwe kerk tot stand nie, maar vervul hulle 'n roeping en is dit 'n uitlewing van hulle geloof in konkrete onderlinge diensbetoon. Die poging om vanuit Handelinge 9:31 die konklusie te mak dat dit kerkregtelik moontlik is om in terme van streekskerke of landskerke te praat en kerkregtelike reëlings op grond daarvan te tref, oortuig nie (Coertzen, 1981:22; vgl. volledige kritiese beskouing hieroor: Du Plooy, 1982:104 e.v.).

Die kerk van Jesus Christus is as die volk van God tegelyk die liggaam van Christus, en kom daarom nie vanuit 'n horisontale of natuurlike dimensie deur middel van die wil van mense tot stand nie. Die kerk is uniek en kan alleen vanuit die koninkryksperspektief begryp word; die verkondiging van die koninkryk van God, waaronder veral verstaan word die heerskappy van God in Christus oor die ganse ekumene, werk kerkvor- 
mend.

God roep sy volk saam deur die bediening van die evangelie, en waar die kerk sodoende ontstaan, ontstaan tegelyk 'n geloofsgemeenskap wat met mekaar in 'n geloofsband te staan kom.

\subsection{Kerkverband}

Die belydenis van die koninkryk van God is die diepste motief vir die eenheid tussen gelowiges en kerke. Die bediening van die evangelie van Jesus Christus as een van die sleutels van die koninkryk van die hemele ontsluit vir elkeen wat dit glo en hom aan God se heerskappy onderwerp dieselfde koninkryk (Heidelbergse Kategismus, Sondag 31). Hier het ons die diepste motief vir die eenheid van kerk oor alle grense heen. Erfgename van die koninkryk van God is inderdaad broers en susters.

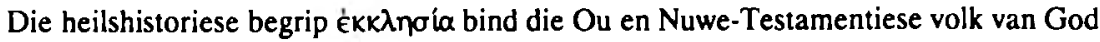
as 'n eenheid saam terwyl ÉkK $\lambda$ noía as Christologiese begrip, die kerk as die liggaam van Christus, alle gelowiges in een liggaam saamverbind, onder die Hoofskap van Jesus Christus. Hy het een heilige volk (1 Pet. 2:9) in al die kerke van die heiliges (1 Kor. 14:33).

Die Nuwe Testament openbaar aan ons dat die kerk katoliek is; dit is algemeen en kan nie in landskerke opgebreek word nie. Oral in die ekumene waar die evangelie verkondig word, onder alle volke, tale en nasies, ontstaan daar die een Godsvolk, en nie volkskerke van God nie. Hiermee word nie beweer dat ons deelgenootskap aan die een Godsvolk ons natuurlike aard en verbondenhede, soos ons geslag en taal en volkskap ophef nie (vgl. Gal. 3:28).

God het sy Woord en Gees en dienste in die kerk gegee om sy een kerk op te bou (1 Kor. 12:28; Ef. 4:11 e.v.; Matt. 16:18). Daar is nie afsonderlike reëlings vir verskillende "streekskerke" gegee nie.

Wanneer ' $n$ bepaalde kerk deur die bediening van die evangelie ontstaan het, is die bande behou met die kerk van wie die evangelie ontvang is (Rom. 15:27; 1 Kor. 14:36).

Daarom vind ons in die Nuwe Testament 'n lewendige verkeer tussen verskillende plaaslike kerke, en nooit hoor ons van 'n kerk in die betekenis van 'n landskerk of streekskerk in die enkelvoud nie. Ons lees in Handelinge 15 hoe kerke mekaar bystaan en help en bindende besluite kan neem omdat dit op Gods Woord gegrond is en 
onder leiding van die Gees geneem is. Die bediening van die Woord het een belydenis tot gevolg gehad (vgl. Hand 16:4; Matt. 16:18; 1 Kor. 12:3).

Ons vind ook dat die dienste en gawes wat God in en aan sy kerk gegee het, nie bedoel was om slegs plaaslik werksaam te wees nie. Dit was gawes en dienste van een Hoof aan die een kerk (1 Kor. 12:28; Ef. 4:11 e.v.). Die besondere dienste was wel aan plaaslike kerke verbind, maar nie gebonde om hulle diens slegs plaaslik aan te wend nie.

Die belewing van kerklike eenheid of geloofsgemeenskap het in die Nuwe Testament grensloos oor die ekumene uitgestrek. Hier is die insameling van die kollekte vir die arm en geteisterde gelowiges in Judea 'n voorbeeld (Hand. 24:17; Rom. 15:25-28; 1 Kor. 16:1; 2 Kor. 8 en 9 ens.). Dit gaan hier nie om iets institutioneels of om geld as

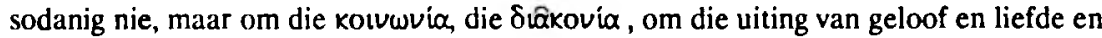
diens aan God (vgl. Du Plooy, 1982:241 e.v.).

\subsection{Wat bepaal lidmaatskap?}

'n Belangrike vraag is: wat bepaal die lidmaatskap van die kerk van Christus?

Dit is inderdaad so dat die enigste kriterium vir lidmaatskap geloof en doop is. Wie verder gaan as dit, na byvoorbeeld ras of volkskap, bring 'n stuk natuurlike teologie in die kerk in.

'n Belangrike aspek in hierdie verband is die kwessie van taal. Mag taal 'n rol speel by die bepaling van lidmaatskap? Sommige meen dat taal geen rol speel nie, en dat dit 'n saak is waaroor die betrokke persoon self moet oordeel. Die probleem is dat geloof en taal sodoende van mekaar geskei word en ons op hierdie manier genade en natuur van mekaar losmaak. Die Skrif laat blyk dat die geloof uit die gehoor van die Woord is (vgl. Rom. 10; Hand. 2:14-23; Heidelbergse Kategismus, Sondag 7:21).

Die belangrikste oorweging is nie - in logiese orde - die eenheidsfaktor nie, maar die evangeliese faktor. Wie die evangelie inderdaad gehoor het, en reg gehoor het, sal begryp dat hy een is met almal wat dit waarlik gehoor en geglo het. Met ander woorde: die hoor en werklike verstaan van die evangelie is bepalend vir die ontstaan van geloof, en dit gaan die eenheid vooraf.

Hieruit lei ons nie af dat taal tot kerklike skeiding aanleiding mag gee nie, maar dat genade en natuur nie teenoor mekaar gestel moet word nie. 


\subsection{Eenheid en verskeidenheid}

Die voorafgaande beredenering bring ons by die bekende onderskeiding van eenheid en verskeidenheid. Van Wyk (1988:19) meen byvoorbeeld dat die bestaan van eie taalgemeentes aanvaarbaar is en as 'n toegewing beskou moet word. Ek meen dat dit prinsipieel verantwoord en as histories-gereformeerd beskou kan word om die instituering van afsonderlike gemeentes as wenslik te beskou - ter wille van die eintlike saak waarom dit in die kerk behoort te gaan, naamlik die hoor en gehoorsame onderwerping aan die Woord van God. Natuurlik mag dit nie aanleiding gee tot 'n verhindering van enige een wat begeerte het om as medegelowige saam te aanbid en saam te luister (al is dit moeiliker) en selfs lidmaat te word nie.

Die begrippe eenheid en verskeidenheid moet inderdaad nie teenoor mekaar gestel word nie. Van Wyk (1988:16) meen dat die eenheid primêr en die verskeidenheid sekondêr is. Ek meen dat hiermee 'n valse probleem geskep word. Ons bely slegs die eenheid van die kerk, maar die vraag is wat ons onder hierdie eenheid in 'n geskape verskeidenheid moet verstaan. Die eenheid is sekerlik dominant en dominerend, maar die verskeidenheid gee 'n rykdom en lewe en kleur aan die eenheid sodat ons nie eendersheid en eenvormigheid kry nie, mar mekaar juis verryk. Hiermee word dus sowel uniformiteit as pluriformiteit afgewys. Die verskeidenheid staan nie langs of teenoor die eenheid nie, maar kwalifiseer dit. Derhalwe sou ek verkies om van 'n eenheid in 'n verskeidenheid te praat. Daar bestaan natuurlik ook ander - selfs meer fundamentele - vorme van verskeidenheid van dienste en gawes en talente. Ek meen dat alle vorme van verskeidenheid wat God self gegee en beskik het daarop gerig is om tot diens en opbou van die Here en sy een kerk op aarde te wees.

\subsection{Meerdere vergaderinge}

Meerdere vergaderinge is volgens Calvyn (Inst. IV, 9) nie die beeld van die kerk nie (vgl. Spoelstra, 1988:46). Sinodes of meerdere vergaderinge is funksioneel ten opsigte van kerkregering en 'n geleentheid waar kerke op grond van hulle konfessionele eenheid saamkom om mekaar by te staan en diensbaar te wees aan die regering van Christus oor sy kerk.

Hierdie diens wat aan mekaar betoon moet word, mag geen grense hê nie. Dit is deel van ons roeping om mekaar in Christus by te staan.

Die fokuspunt by meerdere vergaderinge moet steeds gerig bly op die heil en opbou van die kerk van Jesus Christus waar dit werklik konkreet bestaan, naamlik plaaslik onder leiding van die dienste wat God daarin gestel het. Verder is ' $n$ meerdere 
vergadering iets van ' $n$ belydenis van elkeen wat daarheen afvaardig: dit is ' $n$ erkenning van eie gebrekkige insig en afhanklikheid van ander dienste (persone) in ander kerke aan wie God ook gawes geskenk het om die ander te help en by te staan. Omgekeerd is 'n meerdere vergadering ook 'n daad van roepingsvervulling om naamlik daar te gaan help en te gee van wat van God ontvang is. Hiermee word meerdere vergaderinge iets totaal anders as 'n magsuitoefening omdat dit wesenlik diensbetoning is.

Dit lyk belangrik dat die gereformeerde wêreld sal besin oor die wyse waarvolgens kerklike eenheid in ekumeniese sin - naas formele kerklike vergaderinge soos ekumeniese rade of sinodes - die gemeenskaplike geloof en belydenis moet uitlewe, uitbou en bewaar.

\subsection{Die leer van genade en gelykheid in heil voor God}

Dit is ' $n$ jammerlike feit dat soms (meestal vanuit politieke motiewe) beweer word dat die blankes ' $n$ hoër ras as die swart of gekleurde mense is - asof een volk belangriker voor God as ' $n$ ander kan wees. Dit bots lynreg met Skrifuitsprake soos Galasiërs 3:2628, 1 Korintiërs 12:13 en verwante Skrifgedeeltes. Dit is ook in stryd met die Dordtse Leerreêls, hoofstuk 1 (vgl. dwaling 9): die dwaling is dat geglo word dat die een volk beter is as die ander.

\subsection{Kerklike eenheid het grense}

Kerklike eenheid het inderdaad grense - dit word begrens deur die belydenis. Wie nie een is in belydenis nie, is nie waarlik een nie. Hiermee stel ons nie eenheid en waarheid teenoor mekaar nie, want 'n deel van die waarheid is juis die eenheid.

\section{SLOT}

Kerklike eenheid in en oor volks-en taalgrense heen is primer 'n geestelike eenheid tussen elke lid van die liggaam van Christus, maar dan op grond van die geloofs- en geestelike eenheid met God Drie-enig in en deur Jesus Christus en vanuit die krag van die Heilige Gees.

Dit is 'n eenheid wat ons van God self ontvang het, maar ook met die imperatief om te wees en te word wat ons in Christus is, naamlik een, heilige, algemene (of katolieke) en apostoliese kerk van Jesus Christus. 
Hieruit volg vanself dat ons mekaar konkreet en sigbaar met ons gawes sal dien en bystaan, terwyl ons in liefde die waarheid betrag en die een die ander hoër ag as homself in die gesindheid van Jesus Christus. Gestaltegewing aan hierdie eenheid beteken nie dat ons beperk mag of moet bly tot strukturele reëlings soos in meerdere vergaderinge nie, maar dat ons elke geleentheid sal gebruik om aan God en mekaar diensbaar te wees.

\section{BIBLIOGRAFIE}

ANON. 1989a. Berigte. Die Kerkbode, 143(10):1,25,6. Maart, 17.

kyk

Die Kerkbode. 1989a.

ANON. 1989b. Berigte. Die Kerkbode, 143(11):1,2,6. Maart, 24

kyk

Die Kerkbode, 19896.

BANDA, Ds. 1989. Velkleur-artikel bly, besluit Hervormdes. Die Volksblad: 9, Junie 28.

BRITZ, R.M. 1985. Oor die kerkbegrip en die ordening van die kerklike lewe by die Nederduitse Gereformeerde Kerk. Ned. Genef. Teologiese Tydsknif, XXVI(4):432-451, September.

BUYS, P.W. 1970. Die ekklesiologiese onderskeiding organisme en instituut as antwoord op dic problematiek van die volkskerk. Potchefstroom. (Proefskrif (ThD) - PU vir CHO.)

CALVYN, J. s.j. Institutie of de onderwijzing in de Christelijke religie. Amsterdam : Bottenburg.

COERTZEN, P. 1981. 'n Gereformeerd-kerkregtelike visie op die ekumene. (In Studia historiae ecclesiasticae VII. Kerkhistoriese werkgemeenskap van Suid-Afrika. p. 1433).

COETZEE, J.C. 1965. Volk en Godsvolk in die Nuwe Testament; 'n eksegetiese studic. Potchefstroom : Pro Rege. 329 p. (Proefskrif (ThD) - PU vir CHO.)

COMBRINK, H.J.B. 1986. Perspektiewe uit die Skrif. (In Kinghorn, J. red. Die NG Kerk en Apartheid. Johannesburg : Macmillan Suid-Afrika. p. 211-234).

DE KLERK, PJ.S. 1923. Kerk en Sending in Suid-Afrika. Amsterdam : HA. van Bottenburg.

Die Kerkbode. 1989a. Berigte. 143(10):1,2,5,6. Maart, 17.

Die Kerkbode. 1989b. Berigte. 143(11):1,2,6. Maart, 24.

DU PLESSIS, JA. 1925. Die Gereformecrde Kerk en Kerkregering gehandhaaf teen prof. dr. J. du Plessis van Stellenbosch. Bloemfontein : Nasionale Pers.

DU PLOOY, A. le R. 1979. Ekklesia en meerdere vergaderinge. Potchefstroom. 145 p. (Verhandeling (ThM) - PU vir CHO.)

DU PLOOY, A. le R. 1982. Kerkverband. 'n Gereformeerd-kerkregtelike studie. Potchefstroom. 453 p. (Proefskrif (ThD) - PU vir CHO.)

DU PLOOY, A. le R. 1986. Besinning oor eenheid in kerkverband oor nasionale en taalgrense. (In Smit, C.J., red. In gehoorsaamheid: opstelbundel aangebied aan prof. dr. G.P.L. van der Linde by sy emeritering as hoogleraar. Polchefstroom : PTP. p. 32-49.)

DU PLOOY, A. le R. 1989a. Vrae en suggesties oor die funksionering van die Algemene Sinode (1) en (2) Die Kerkblad: 5-6, Julie 5 en 19.

DU PLOOY, A. le R. 1989b. Kollegialisme. In die Skriflig, 23(91): 2-11.

ENGELBRECHT, BJ. 1978. Die vraag of (die) drie (susters-)kerke met een en dieselfde belydenis binne een en dieselfde volk (met dieselfde taal, geskiedenis en kultuur) mag bestaan in die lig van Bybels-Reformatoriese visie oor die eenheid van die kerk van Jesus Christus. Almanak en Bybelse Dagboek: Algemene Kerkvergadering van die Nederduitsch Hervormde Kerk van Afrika 72:15-18. 
FOURIE, D.C.G. 1973. Die Nederduitse Gereformeerde Kerk as regspersoon in die Suid-Afrikaanse privaatreg. Potchefstroom. (Proefskrif (D Jur) - PU vir CHO.)

Handelinge van dic nasionale sinodes GKSA. 1958, 1961, 1967, 1970, 1973, 1976, 1985, 1988.

Handelinge van die Tussenkerklike Kommissie van die drie Afrikaanse Susterkerke. Deel I (1955-1977), deel II (1978-1981), deel III (1982-1989).

HEYNS, J.A. 1977. Die Kerk. Pretoria : N.G. Kerkboekhandel.

JAFTHA, C.D. 1988. Respons. In die Skriflig, 22(85):33-36, Maart.

JONKER, W.D. 1989. Die pluriformiteitsleer van Abraham Kuyper. In die Skriflig, 23(91):12-23, September.

KLEYNHANS, E.PJ. 1973. Die kerkregtelike ontwikkeling van die N.G. Kerk in Suid-Afrika, 1795-1962. Stellenbosch. (Proefskrif (Th.D.) - Universiteit van Stellenbosch.)

KLEYNHANS, E.P.J. 1977. Ons kerklike verhoudinge - in kerkhistories-kerkregtelike perspektief gesien. Ned. Geref. Teologiese Tydskrif, 18(4):301-316.

KUYPER, A. 1884. Tractaat van de Reformatic der Kerken. Amstcrdam : Höveker en Zoon.

KUYPER, A. 1909. Encyclopaedic der heiligen Godgelecrdheid II, 2de druk. Kampen : Kok.

MACPHERSON, J. s.a. Presbytcrianism. Edinburgh : Clark.

McNEILL, J.T. 1988. Calvin as an Ecumenical Churchman. Church History, vol. 57. Supplement: 43-55.

NED. GEREF. KERK. 1975. Ras, volk en nasie en volkereverhoudinge in die lig van die Skrif. Kaapstad N.G. Kerkuitgewers.

NED. GEREF. KERK. 1986. Kerk en Samelewing. 'n Getuienis van die Ned. Geref. Kerk. Blocmfontein : NG Sendingpers Blocmfontein.

OBERHOLZER, BART. 1990. Eenheid van kerke bespreck. Beeld: Julie, 6.

OORTHUYS, G. \& KROMSIGT, PJ. 1933. Grondslag en wezen der Kerk. Wageningen : Veenman \& Zonen.

PONT, A.D. 1981. Die historiese agtergronde van ons kerklike reg. Akademiese handboekc, deel I. Pretoria/Kaapstad : HAUM.

PONT, A.D. 1986. Verbond en volkskerk. Henvormde Teologiese Studies, 42(1):28-76, Maart.

PONT, A.D. 1987. Die vrye kerk: Enkele opmerkings oor die herkoms en inhoud van die opvalting. Hervomide Teologiese Studies, 43(1\&2):25-46, Maart/Junie.

SNYMAN, WJ. 1977. Nuwe en ou dinge. "Uil die skat van die koninkryk". Potchefstroom : Pro Rege.

SPOELSTRA, B. 1984. Die invloed van Calvyn op die geldende kerkordes in Suid-Afrika 1652-1983. Srudia historiae ecclesiasticae $X$, Kerkhistoriese werkgemeenskap van Suid-Afrika: 50-75.

SPOELSTRA, B. 1988. Kerkecnheid en meerderc kerkevergaderings. In die Skriflig, 22(85):37-52, Maart.

THERON, P.F. 1986. Kerklike eenheid en natuurlike verskeidenheid. (In Kinghorn, J., red. Die NG Kerk en Apartheid. Johannesburg : Macmillan Suid-Afrika. p. 194-210.)

VAN AARDE, A.G. 1989. 'n Nuwe-Testamentiese begronding van die kerk en die eis om kerkeenheid vandag. Hervomde Teologiese Studies, 45(2):461-475, Junie.

VAN DER WESTHUIZEN, H.G. 1989. Twaalf keer volkskerk. Die Henvormer. 11, November.

VAN DER WESTHUIZEN, H.G. 1989. Twaalf keer volkskcrk. Die Henonner. 9, Desember.

VAN WYK, DJ.C. 1985. Status confessionis en Belharbelydenis: Agtergrond. inhoud en voortgaande gesprek. Henormde Teologiese Studies, 41(1):49-77, Februarie.

VAN WYK, J.H. 1988. Kerkeenheid: 'n Perspektief op die verhoudinge in die Gereformeerde Kerke in Suidelike-Afrika. In die Sknjlig, 22(85):16-32, Maart.

VAN ZYL, F.J. 1978. Vereniging of samewerking? Almonak en Bybelse dagboek: Algemene Kerkvergadering van die Nederduitsche Hervormde Kerk van Afrika 72:23-26.

WALLACE, R.S. 1959. Calvin's Doctrine of the Christian Life. Edinburgh : Scottish Academic Press.

WOOD, J.E.(jr.). 1990. Editorial: Religion and National Interests. Joumal of Church and State, 32(1):7. 16 , Winter. 
